Conscientious Objections to Corporate Wrongdoing

\title{
Bad Followers?
}

Knights and O'Leary (2005) posit that "some, if not all, of the ethical problems in corporate capitalism revolve around a failure of leadership" (p. 359). From their examination of corporate scandals, they concluded that:

Leaders created a culture that emphasized financial performance, targets and individual and corporate success and leaders either engaged directly in unethical practices, ignored the unethical practices of employees when it was brought to their attention, or failed to provide adequate support or training, let alone ethical guidance, for employees (Knights and O'Leary 2005 p. 365).

However, those who follow bad leaders cannot avoid taking a share of responsibility.

Followership, as Robert Kelly (1992) contends, accounts for more than $80 \%$ of the success of any project within an organization. Some followers, as Milgram (1974) amply demonstrated, simply obey orders to appease, profit from, or defer to, authority. They are "acolytes" (Kellerman 2004 p. 26). Other followers need little inducement to behave badly. They do so as much for their own debased reasons as those of their leaders. Kellerman (2004) describes them as "evildoers" (p. 27). Still others follow out of fear or a lack of resolve. They are "bystanders" (Kellerman 2004 p. 27). A fourth, and growing, category of followers is the "isolates" (Kellermen 2008 p. 86). Isolates take no interest in others or their circumstances. Their disengagement keeps them ignorant, inert, and apathetic. They merely "do what they must to get by and no more" (Kellerman 2008 p. 91).

Whether directly involved in wrongdoing or not, none of these followers can claim exemption from complicity. While acolytes and evildoers are eager to lend their support in exchange for perceived benefits, the inaction of bystanders and isolates brings them no less discredit. While they are not absentees, they act as if they, and 
Conscientious Objections to Corporate Wrongdoing

worse still, others, were (Wiesel, 1969). Although abstention from direct participation may appear to offer a defense against culpability, the weight of historical evidence from an ever-expanding catalogue of 'crimes of obedience' (Kelman and Hamilton 1989), clearly demonstrates that there is neither virtue nor vindication in reticence when speaking up and out could curtail or prevent malfeasance. Non-participation does not equate to non-partisanship.

Bad leaders would not be able to realize their ambitions without the support of dedicated, opportunistic, docile, or indifferent followers. Their success is assured by the complicity of the silent majority. Going along with villainy certainly resolves the dilemma of self-sacrifice. Yet, allegiance to bad leaders makes little, if any, practical, let alone moral, sense, even from a strictly utilitarian point of view (Gustafson 2013). There may be some immediate gain in being a follower of such leaders, but this is unlikely to be lasting. Moreover, followers tend profit less than leaders. How, then, is the greatest good of the greatest number of followers served by being led to corporate ruin?

In what follows, it will be argued that there is greater good in following one's own conscience than being led by the unconscionable behavior of a bad leader. There are, in contradistinction to those who go along to get along, another class of corporate employees. These are individuals prepared to voice disquiet. They are principled dissenters, more commonly referred to as whistleblowers. As whistleblowing has shown, the exposure of corporate wrongdoing is not only owed a greater debt than it is paid to, but may also be more assured by, liberty of conscience, than mere reliance on official internal or external safeguards such as codes of conduct or government regulation. 
Conscientious Objections to Corporate Wrongdoing

The discussion begins with an examination of two primary instruments for regulating organizational behavior, i.e., legislation and codes of conduct. Though necessary, these measures are an insufficient deterrent against misconduct and misdeeds. Prohibition is one thing, but adhering to it, is quite another. Rules and regulations do not, indeed cannot, ensure compliance (Graeber 2015). They can, however, be bent, broken, abused, distorted, disputed, unenforced, or otherwise subverted, and, of course, simply ignored. Something deeper and more gripping is necessary to generate and sustain employees' allegiance to the rules. Conscience, it is argued, can offer a strong, first line of defense and attack against corporate wrongdoing. The paper analyzes the nature of conscience and its cultivation within organizations, i.e., conscientization. Conscientization or conscience raising, makes blowing the whistle, or more precisely, conscientious objection, possible, the essential elements of which are listed and discussed. The paper concludes with suggestions for invoking the consciences of company employees, most notably through the medium of storying.

\section{Legal and Ethical Codes}

A range of legislative requirements have been either strengthened or developed to counter the incidence of corporate wrongdoing. In the 1980s, the U.S. government became increasingly aware that the fines and penalties imposed by regulators were inadequate to deter or punish corporate crime. Fines were often so low that companies were writing them off as business expenses. Company laws were consequently amended. The result, modelled in many respects on the Defense Industry Initiatives, was the 1991 U.S. Sentencing Guidelines for Organizations. The Guidelines specified harsher penalties for corporate lawbreakers, indexing fines at between two and three times the financial damage caused by offenders. However, in the decade following the introduction of the guidelines it became evident that 'no one knew exactly how many 
Conscientious Objections to Corporate Wrongdoing

organizations (including for- and non-profit, privately or publicly held corporations) were in complete compliance with these rules' (Rafalko 2003 p. 116).

As the failure of these provisions demonstrated, legislation alone cannot gauge the full extent of wrongdoing, nor is it an adequate guide to doing what is right. An act might be lawful, but unethical, and vice versa. The law is simply proscriptive. Legal sanctions have also long been shown to be implicated in producing and amplifying the very deviance they were designed to control (Marx 1981). Laws focus far more on the culprits of, than the conditions that facilitate, corporate wrongdoing (Vaughn 1982), and tends to be retributive and retrospective rather than corrective or preventative (Moberly 2006).

Another key instrument used to hold corporations and their employees accountable for their behavior are codes of conduct. Codes of conduct and compliance programs are now conspicuous features of a growing number of business organizations (Wright and Rwabizambuga 2006). Indeed, not only have codes of conduct proliferated at company, but also at sub- and supra-organizational, levels (Preuss 2009). By 2006, $52.5 \%$ of the 200 largest companies in the world had a code of conduct in place (Kaptein 2006). Regulatory agencies and stakeholders have made it imperative for companies without a code of conduct to develop or adopt one.

Codes of conduct became most prominent in the US during a time of corporate crisis, beginning with the electrical equipment industry price-fixing turmoil of the $1960 \mathrm{~s}$, the foreign payments fiasco of the 1970s, the insider trading and related RICO prosecutions of the 1980s, and the defense procurement fraud of the same decade (Pitt and Groskaufmanis 1990). In 1991, Congress made proof of an effective corporate code of conduct a mitigating factor under the Federal Sentencing Guidelines for Organizations (Harvard Law Review 1996). With the collapse of Enron, the Securities 
Conscientious Objections to Corporate Wrongdoing

and Exchange Commission (SEC) introduced new implementing rules, and sections 406 and 407 were added to the Sarbanes-Oxley Act (2002), as measures designed to tighten ethical compliance, particularly amongst corporate leaders (Moberly 2006).

Despite assurances about the deterrence effect of codes of conduct, their effectiveness remains in serious doubt (Kaptein 2011). For example, close examination of the legislative amendments made in the aftermath of the Enron scandal suggests that these measures are unlikely to stem the flow of corporate misconduct and may even hamper genuine efforts to use the codes effectively (Rafalco 2003). In essence, they tempt corporations to offset the burden of additional reporting requirements by narrowing the scope of codes and ensuring that they are scripted in ways that are more attuned to the letter rather than spirit of the law (Harvard Law Review 2003).

Codes of conduct are voluntary and self-regulatory devices (Katein and Schwartz 2008), and their content and emphasis vary considerably (Kaptein 2004). A post-Enron content analysis of the codes of the world's 50 largest multinational corporations $(\mathrm{MNC})$ found that greater emphasis was placed on managing conduct against than on behalf of the company. Relations with investors and consumers, civic and community affairs, and product safety were of much less concern to these corporations than conflicts of interests (Carasco and Singh 2003). Enron (2000) had itself devoted almost three pages of its code of conduct to such clashes. The study made it clear that corporate social responsibility was not these MNCs highest priority. By the same token, while the codes of conduct of MNCs tended to place greater emphasis on minimizing internal graft, the performance of these corporations in policing their own codes has highlighted the deep chasm between rhetoric and reality.

The reality, according to Friedmanites, and followers like them, is that business men and women who: 


\section{Conscientious Objections to Corporate Wrongdoing}

believe that they are defending free enterprise when they declaim that business is not concerned 'merely' with profit but also with promoting desirable 'social' ends ... are unwitting puppets of the intellectual forces that have been undermining the basis of a free society these past decades (Friedman 2007 p. 173).

The calamitous fate of corporations, even those thought 'too big to fail' (Sorokin, 2010), bent on the pursuit of profit as an end in itself, or what Goodpaster (2000) has dubbed "teleopathy" (p. 189) is now well known. Teleoapthy, a derivative of the Greek terms for "goal" and "disease," is according to Goodpaster (2007):

the unbalanced pursuit of purpose in either individuals or organizations. This mindset or condition is a key stimulus to which ethics is a practical response. The principal symptoms of teleopathy are fixation on intangible goals or purposes without moderation, a tendency to rationalize or even deny responsibilities and realities that might impede the accomplishment of those goals and purposes, and a general separation of the ethics of business goals from the ethics of everyday life, leading to emotional detachment regarding the full human implications of pursuing these goals" (italics original) (p. 28).

Nevertheless, "calls for integrity and responsibility in institutional life, even in the wake of scandals, soon lose energy and effect. Like pebbles in a pond, their initial splash dissipates and seldom results in very much structural or cultural change" (Goodpaster 2000 p. 192). Hence, the mere existence of a code of conduct is not enough to exert a lasting influence on ethical behavior (Kaptein 2011).

\section{A Matter of Conscience}

Legislation and codes of conduct are merely surrogates for conscience. Right conduct is ultimately a matter of private conscience, i.e., the "rich set of practical moral 


\section{Conscientious Objections to Corporate Wrongdoing}

skills" that "makes us broadly aware of the actual moral quality of our own and others' conduct" (Brownlee 2012 p. 2). A recent study by Holtbrügge, Baron, and Friedmann (2015) found that "individuals who are not committed to their internal standards adopt a pragmatic orientation, tailoring their ethical attitudes to fit whatever the situation seems to call for" (p. 275). Conversely, the study confirmed that the prevailing organizational culture, whether controlling or flexible, had significantly less influence on the ethical attitudes of principled individuals. Although the authors point out that this scenario may be typical of firms operating in highly individualistic cultures (Hofstede 2001), recent research on firms in traditionally collectivist cultures (Hofstede 2001) has shown that employee ethics are, indeed, a significant factor influencing the level of collective commitment towards company performance (Chun, Shin, Choi, and Kim 2011).

Albinger and Freeman (2000) note that an organization's attitude to corporate social performance, i.e., its social conscience, influences job selection. A study by Hagenbuch, Little and Lucas (2015) found that "prospective employees were least attracted to firms that integrated their social and financial goals" (p. 83). The ideal of conflating economic and social goals is liable to raise (healthy) skepticism among discerning employees looking to be personally involved in corporate benevolence in a business environment where 'laws and norms pressure corporations to alienate and suspend ethical judgment' (Goodpaster 2000 pp. 191-2).

As Constantinescu and Kaptein (2015) point out, individuals bear as much responsibility for (un)ethical attitudes and behavior as the corporations they work for. However, not only are individuals more amenable to change, they are also the harbingers of organizational transformation. The starting point for maintaining right conduct or prompting ethical reform is individual conscience. 
Conscientious Objections to Corporate Wrongdoing

\section{Conscience and Conscientiousness}

Humans possess a unique sense of propriety, or more broadly, a moral sense, which guides their conduct from early childhood. Individuals' ability to tell right from wrong typically begins as early as age four (Nunner-Winkler and Sodian 1988). By the age of seven or eight most children are able to discriminate between anti- and pro-social behavior (Malti and Krettenauer 2013). Even psychopaths are capable of knowing the rules, both moral (Steven, Deuling and Armenakis 2012) and legal (Vitacco, Erickson, and Lishner 2013). However, bending and breaking these is of little or no consequence to them (Blair 2011). Small wonder, then, that the worst excesses of corporate malevolence and malfeasance are frequently attributed to these individuals (Babiak and Hare 2006), particularly those who supervise, manage, and lead (Babiak, Neumann, and Hare 2010). Fortunately, psychopaths are estimated to be few in number (approximately 1\% of the general population) (Neumann and Hare 2006), and claims about their success in business have been highly exaggerated (Harris, Skilling, and Rice 2001). Most known psychopaths are either in, likely to return, or be sent, to jail, and account for a minority (an estimated 15\%) of the prison population (Erikson and Vitacco 2012).

Central to the modern conception of conscience is the notion of a capacity, attributed to most people, that enables them to discern the commission or omission of acts, both their own and others,' as immoral and blameworthy (Strohm, 2011). Its meaning emanates from the Greek term suneidesis, and Latin derivative, conscientia, both of which connoted a state or act of sharing knowledge or simply knowledge, awareness, or apprehension (Sorabji, 2014). While the etymology of the term retains this double meaning, modern interpretations have lost much of the nuance that makes the notion of conscience distinctive and significant. As Langston (2001) observes: 
Conscientious Objections to Corporate Wrongdoing

Perhaps the long-standing identification of conscience with some set of rules for behavior undercuts its importance. We follow the rules we formulate or are given and try to deduce even more. This reasoning seems much like ordinary moral discussion and need not be out under the notion of conscience. Once we remove moral reasoning from conscience, it appears that the only function of conscience is to goad us to proper behavior by making us feel uncomfortable when we do other than we should. Yet, this reduction of conscience to an emotional buzzer hardly preserves the notion of conscience (p. 1).

Particular conceptions of conscience fall within two extremes (Hill 1998). A one end of the spectrum, conscience is providential. At the other, conscience is culturally derived and normative. Whether moved by learning or epiphany, whatever suasive effect one's inner conscience has is relative. Relativity is not problematic in and of itself. A major problem arises, however, when conscience is unreflective, i.e., dogmatic or doctrinaire (Pianalto 2011). Conscience guided by unreason has driven true believers to excess. Both blind faith and false consciousness have stirred and sanctioned unconscionable behavior of unprecedented proportions from the crusades to the inquisition and (now back) to holy war.

On the face of it, it might seem right to condemn submission to conscience, and not just in business. However, it is extremely difficult to divorce oneself or escape from conscience. Who now can deny the Holocaust as matter of conscience? Conscience signals contraventions ranging from minor infractions to capital offences, and it serves as a constant reminder of these. Moreover, conscience is not simply intuitive. Nor is it merely the internalized strictures of dogma or culture. Conscience can be honed through a process of conscientization (Freire 1970), combining critical reflection and action. 
Conscientious Objections to Corporate Wrongdoing

Thomas Hill (2000) offers a conception of conscience that deftly avoids the contentious problems associated with the metaphysical (faith-based) and deflationary (normative) extremes, parochialism and fundamentalism in particular, and at the same time addresses two key questions, i.e., to what extent and why should individuals (1) treat their conscience as authoritative moral guides, and (2) respectfully tolerate the conduct of others when they are apparently guided by conscience?

Hill (1998) notes that individuals are bound to regard their moral sense as decisive since there is no unimpeachable alternative. Moreover, each person has a range of inner (celestial and terrestrial) voices of conscience at their disposal. Nevertheless, while conscience commands respect, it is not foolproof. It is possible for conscience to become misguided, at least for a time. Again, consider the Holocaust. But, in the final analysis, conscience remains a person's most trusted guide. As Hill (1998) explains, although "a clear conscience is no guarantee that we acted in an objectively right way, it is both necessary and sufficient for morally blameless conduct" (pp. 35-6). The margin of error can be significantly reduced when individuals subject their consciences to deliberate scrutiny and test the force of their moral convictions in public. The imperative to certify the authority of one's own conscience is a feature generally lacking in conceptions of conscience based on creed and culture.

In claiming moral authority for their own consciences, individuals are obliged to recognize the authority of others as equal. By the same token, other people's consciences are also subject to error, and hence, must be held to account. Moral agreement is not always possible. However, disagreements provide opportunities for those involved to reconsider their original conscientious judgments, and accede to those of others when warranted. In the event of a moral impasse, one's own conscience prevails, provided it has satisfied the requirements of judicious introspection and 
Conscientious Objections to Corporate Wrongdoing

reasoned debate. This entails asking oneself a series of searching questions. Was I really applying a sound moral principle to my actions, or was I making a self-serving exception? Did I correctly perceive the morally relevant features of my circumstances, or was I engaging in wishful thinking or some other form of self-deception? Was I adequately attentive and diligent in my moral accounting? Was I blindly influenced by others or by the culture at large? It is this kind of self-criticism, the introspective critique of individuals' own prior moral reasoning that Hill (2000) claims is a precondition for conscientiousness.

\section{The Test of a Good Conscience}

The forgoing raises a number of important points to consider in cultivating and engaging the consciences of followers. For conviction to be genuinely conscientious, i.e., derived from a sound conscience, it must be consistent, universal, non-evasive, and communicated (Brownlee, 2012). As Kimberly Brownlee (2012) has argued, when individuals carry a conscientious conviction that something is wrong, they must (1) avoid the conduct in question to the best extent that they are able; (2) judge such conduct in others to be wrong also; and must be willing (3) to bear the risks of honoring their conviction; as well as (4) communicate the reasons that they think justify their conviction to others. These conditions, elaborated below, are the measure of a good or clear conscience.

\section{Consistency}

Conscience is neither exceptional nor extraordinary. The ability to use conscience in a discriminating manner typically develops early in life, and evolves with experience and maturity. Most people grow accustomed, and respond in one way or another, to its urgings. It is not the source of virtues, nor, indeed, values, but rather the basis for judging and defending these. As Hill (1998) contends, conscience is neither an 
Conscientious Objections to Corporate Wrongdoing

instinct nor a faculty for determining right and wrong. Rather, it serves as an internal process of "judicial self-appraisal" (p. 31). Conscience makes individuals aware of, and accountable for, their moral convictions. A guilty conscience in particular, is hard to ignore or disown without incurring considerable cognitive dissonance, emotional turmoil, and self-admonition. Nevertheless, it affirms as well as negates.

Conscience functions as a guide to ethical behavior. Followers are obliged to take all due care in consulting their consciences and arriving at their most reasonable judgments about what is wrong and right (Brownlee, 2012). Judgments must be thoroughly probed by them before acting on these. Their appraisals would simply be rash, impulsive, sanctimonious and, hence, inconsistent, otherwise. However, while conscience acts as a guide to moral behavior, this does not diminish its stature, nor justify dismissing or overriding it.

\section{Universality}

Although conscience is personal, it is not insular. It urges individuals to think for, but not only about, themselves when considering their moral responsibilities. Conscience raising is a necessarily interactive enterprise undertaken in collaboration with others, including, and indeed, most especially, those who are single- and narrow-, as well as like-minded. It requires individuals to recognize when an act they judge to be wrong is wrong not only when they commit it, but also when others in similar circumstances do it. Followers are not consigned to silent contemplation and protest about moral transgressions that affect others in the same or similar way as themselves. Active conscientious objection is not only possible in such circumstances, but also imperative. Followers have both a right and an obligation to object to, resist, and put a stop to immoral and unethical acts and directives, and the enveloping doctrines, systems and regimes which give rise to, and perpetuate, these. 
Conscientious Objections to Corporate Wrongdoing

\section{Non-Evasion}

The ultimate authority for any appeal to conscience is oneself. There is no requirement to look to those in authority for guidance in exercising conscience. Needless to say, people in authority are not, by simple virtue of their position, authoritative, and there is no unswerving reason to steer one's own conscience by them. One ought to regard one's conscience as one's surest moral compass. Followers are, thus, morally accountable for their actions. Obedience to authority which exceeds the bounds of propriety is no less a moral than legal violation (Kelman and Hamilton 1989). Followers cannot evade moral responsibility by simply claiming to be the instruments or victims of unscrupulous leaders. There is no denying that disobedience carries a risk, but it remains a moral choice, even under duress. "Followers who knowingly, deliberately commit themselves to bad leaders are themselves bad" (Kellerman 2004 p.

25). But, no matter how diligent conscientious reflection and exhaustive deliberative discourse have been, neither guarantees infallibility. The moral judgments rendered by conscience are subjective. However, despite any residual doubt, scrupulous, methodical reasoning sharpens the quality of moral viewpoints, and although they remain subjective, removes any basis for unmitigated recrimination or retribution against those who earnestly follow their consciences.

\section{Communication}

Conscience is not only introspective, but also retrospective and prospective (Sulmasy 2008). It alerts followers to their own and others' misdeeds and serves as a prelude to further conscientious deliberation. It voices the inner conflict that occurs when what they and others have done, are doing, or are about to do, violates their moral sensibilities, and speaks in a moral vocabulary that they have grown to recognize, understand and articulate as their own. 
Conscientious Objections to Corporate Wrongdoing

Although people are not at liberty to do whatever they please, those in authority have no jurisdiction over their private consciences. Authorities may be in a position to impose sanctions on people's actions. However, any attempt to censor or muzzle individuals' consciences not only constitutes a gross violation of moral integrity, but also a basic human right. As Kukathas (2003) notes, "among the worse fates that individuals might have to endure is being unable to do what they think is right" (p. 55).

\section{The Development of a Collective Conscience}

In contrast to democratic institutions, those employed in private enterprise are generally expected to place corporate, above other, interests (Weitzel and Rodgers, 2015). They are not typically given leave to mandate company policies, practices or priorities. How, then, can conscientiousness be fostered and harnessed within corporations, especially those led and managed by individuals not renown for developing and maintaining a culture in which employees are at liberty to voice their ethical concerns?

A number of proposals have been advanced for making firms more virtuous (e.g., Bazerman and Tenbrunse 2011; Goodpaster 2007; Gentile 2012; Misangyi, Waver and Elmas 2008; Moore 2015; Morales-Sánchez and Cabello-Medina 2015; Weaver 2006). Nevertheless, as admirable as these schemes are, they invariably miss the point. There is no absence of virtues in corporations. Rather, the problem lies in upholding these with firm conviction. Ways of cultivating private conscience are required that depart from conventional routes of incorporation. The novelty lies in simplicity, i.e., simply lessening the distinction between one's own and others' fate. Introspection and sociality are, in practical terms, the keys to conscience building. It may well be the case that those who are willing to follow bad leaders (evildoers, acolytes, bystanders and isolates) outnumber those opposed to them. However, as corporate history has shown, 
Conscientious Objections to Corporate Wrongdoing

particularly in recent times, personal conviction is, in a very real sense, the wellspring of collective conscience.

While US corporations differ from democratic institutions, they nevertheless operate in a democracy accustomed to principled dissent. And, as Hofstede (2001) made clear, in contrast to collectivistic societies, those with highly individualistic cultures such as the United States, are far less subservient to hierarchy and tolerant of unjustified abuses of power and authority. Every organization is replete with employees who have a conscience and, hence, capacity for conscientious objection (Graham 1986). No organization can stunt moral acuity nor mute dissent. Concerted action arising from a single, discrete impulse to depart from unconscionable conventions and norms is always possible. The chief catalyst for conscientization is the "internal witness" (Miceli and Near 2013 p. 436) or "institutional entrepreneur" (Misangyi, Weaver and Elms 2008 p. 750), otherwise known as whistleblowers (Devine and Maassarani 2011), i.e., persons prompted by moral conviction to expose the illegal, immoral, or illegitimate practices under the control of their or others' current or former employers, including those resulting from omission as well as commission, that affect others no less than themselves (Bedau, 1991; Miceli and Near 2013).

Although whistleblowing tends to be depicted in negative terms, research confirms that most of those who blow the whistle do not experience reprisals and other negative consequences (Miceli and Near 2013). Indeed, international research has shown a degree of positive regard for whistleblowing (Skivenes and Trygstad 2010). Evidence suggests that not only does threatening retaliation fail to discourage many whistleblowers, but it also encourages some to report wrongdoing to the media and other outsiders (Miceli, Near and Dworkin 2008). In addition, legal protection for 
Conscientious Objections to Corporate Wrongdoing

whistleblowing in the US is considered among the strongest by international standards (Miceli and Near 2013).

The Dodd-Frank Act (2010) introduced after the scandals that precipitated the 2008 financial crisis, recognized the importance of employees' consciences, and was, among other things, designed to encourage whistleblowing. Section 922 of the Act, a previously obscure provision, dramatically expanded incentives for whistleblowing by requiring the SEC to pay hefty bounties for useful information regarding securities law violations and enhancing retaliation protections for informants (Harvard Law Review 2011). Thus, the moral convictions of followers are of greater importance than has ever been the case previously, and is perhaps, more so now than those of leaders, in which case, unquestioning reliance upon their leadership and management is bound to be much less assured than it has been in the past, and ought to make followers more attentive to the ethical dispositions of their coworkers. This is a point that corporate recruitment, induction and training programs need to highlight, and performance appraisals, bonuses and promotions reinforce.

It is possible to institutionalize anonymous and incentivized reporting of wrongdoing (Miceli, Near, and Dworkin 2008). However, this must be tempered by moral edification if vigilance is to avoid becoming little more than surveillance, and followers being reduced to informants and bounty hunters. Publicizing stories of principled dissent, by contrast, can serve to strengthen employees' moral identity and agency (Weaver, 2006). They can be used to provide an enduring legacy and inspiration to others. As Bazerman and Tenbrunsel (2011) explain:

A Fortune 50 corporation, produced a video of four stories by four employees who went above their bosses' heads to keep the corporation from acting unethically. Each tells his or her story in vivid detail and stresses that he or she 
Conscientious Objections to Corporate Wrongdoing

was simply doing what was needed to behave ethically. The video is widely shown within the organization. At the end of the video, we learn that all four whistleblowers now hold very senior positions in the corporation (p. 162).

The video was the result of conscientious objection by ordinary employees to the impropriety of those above them, and "it had a lasting, powerful effect because the stories are repeated through informal channels" (p. 162).

Storying is, of course, not new. The novelty resides in using it to expose and deter corporate crime and corruption. The development of principled followership is apt to stem from a consideration of the facts, as well as an appeal to the moral of, and sentiments, conveyed by the stories showcased. Stories demystify whistleblowing, by clarifying the nature, as well as vivifying and contextualizing the destructive effects, of wrongdoing. A focus on the rudiments of both thinking and feeling in storytelling has the potential to create the sense of moral awareness, acuity and solidarity noted earlier. It serves to disrupt the invidious dichotomies between 'us and them,' 'leadersfollowers,' etc., that pit good against bad consciences, and thereby, engender richer, dialectical relationships between 'you and me' and 'all of us,' 'together,' etc.

\section{Conclusion}

Various explanations have been proposed for the ultimate cause of corporate wrongdoing in recent years, particularly in regard to the long list of felonies committed by once large, powerful, respected, and above all, trusted, global corporations (Nieuwenboer and Kaptein 2008). However, a seemingly unnoticed reason for corporate ruin is a lack of conscience. This is perhaps not surprising given the common disregard for conscience in business (Stout, 2006; Weitzel and Rodgers, 2015). Little wonder that nothing appears to have stood between corporate executives at Adelphia, Dynegy, Global Crossing, HealthSouth, Lehman Brothers, Qwest, Sprint, Vivendi, 
Conscientious Objections to Corporate Wrongdoing

Tyco, Worldcom, Enron, Volkswagen, among others (Patsuris 2002), and their unconscionable behavior. If moral obligation were as strong and pervasive as the pursuit of profit, then there would be no cause for concern. In instances where corporations attempt to cheat justice, moral, may be harder than legal, conviction to elude. Giving conscience's counsel its due, serves to curb the teleopathic behavior of corporate leaders and followers, and fortify or restore a sense of propriety. Doing business with a clean conscience is simply good business. 
Conscientious Objections to Corporate Wrongdoing

\section{References}

Albinger, H., and Freeman, S. 2000. "Corporate social performance and attractiveness as an employer to different job seeking populations," Journal of Business Ethics 28: $243-253$.

Babiak, P. 2000. "Psychopathic manipulation at work," in C. Gacono, ed., The clinical and forensic assessment of psychopathy: A practitioner's guide. Lawrence Erlbaum Associates: London, pp. 287-311.

Babiak, P., and Hare, R. 2006. Snakes in suits: When psychopaths go to work. HarperCollins: New York.

Babiak, P., Neumann, C., and Hare, R. 2010. "Corporate psychopathy: Talking the walk," Behavioral Sciences and the Law 28: 174-193.

Bedau, H. Ed. 1991. Civil disobedience in focus. New York: Routledge.

Blair, R. 2011. "Moral judgment and psychopathy,” Emotion Review 3: 296-298.

Brazerman, M., and Tenbrunsel, A. (2011). Blind spots: Why we fail to do what's right, and what to do about it. Princeton: Princeton University Press.

Brownlee, K. (2012). Conscience and conviction: The case for civil disobedience. Oxford: Oxford University Press.

Carasco, F., and Singh, J. 2003. "The content and focus of the codes of ethics of the world's largest transnational corporations," Business and Society Review 108: 7194.

Chun, J., Shin, Y., Choi, J., and Kim, M. 2011. "How does corporate ethics contribute to firm financial performance? The mediating role of collective organizational commitment and organizational citizenship behavior," Journal of Management 39: 853-877. 
Conscientious Objections to Corporate Wrongdoing

Ciulla, J. 2005. "The state of leadership ethics and the work that lies before us," Business Ethics: A European Review 14: 323-335.

Constantinescu, M., and Kaptein, M. 2015. "Mutually enhancing responsibility: A theoretical exploration of the interaction mechanisms between individual and corporate moral responsibility," Journal of Business Ethics 129: 325-339.

Devine, T., and Maassarani, T. (2011). The corporate Whistleblower's survival guide: A handbook for committing the truth. San Francisco: Berrett-Koehler.

Enron Code of Ethics. 2000. http://www.thesmokinggun.com/file/enrons-code-ethics, accessed 28 September 2015. From the Smoking Gun website.

Erickson, S., and Vitacco, M. 2012. "Predators and punishment," Psychology, Public Policy and Law 18: 1-17.

Freire, P. 1970. Pedagogy of the oppressed. New York: The Continuum International Publishing Group Inc.

Friedland, J. 2012. "Beyond empiricism: Realizing the ethical mission of management," Business and Society Review 117: 329-356.

Friedman, M. 1970 September 13. "The social responsibility of business is to increase its profits." The New York Times Magazine 173-178, fille://Users/johnsolas/Documents/Work\%20Files/Publications/ARTICLES/Orga nizations/BSR/Resources/The\%20Social\%20Responsibility\%20of\%20Business\% 20is\%20to\%20Increase $\% 20$ its\%20Profits, $\% 20$ by $\% 20$ Milton $\% 20$ Friedman.html, accessed September 2, 2015.

Garrett, B. 2014. Too big to jail: How prosecutors compromise with corporations. Cambridge: Harvard University Press.

Gentle, M. (2012). Giving voice to values: How to speak your mind when you know what's right. New Haven: Yale University Press. 
Conscientious Objections to Corporate Wrongdoing

Goodpaster, K. 2000. "Conscience and its counterfeits in organizational life: A new interpretation of the naturalistic fallacy," Business Ethics Quarterly 10: 189-201.

Goodpaster, K. 2007. Conscience and corporate culture. Oxford: Blackwell.

Graeber, D. 2015. The utopia of rules: On technology, stupidity, and the secret joys of bureaucracy. Brooklyn: Melville.

Graham, J. W. 1986. “Principled organizational dissent: A theoretical essay,” Research in Organizational Behavior, 8: 1-52.

Gustafson, A. 2013. "In defense of a Utilitarian business ethic," Business and Society Review 118: 325-360.

Hagenbuch, D., Little, S., And Lucas, D. 2015. "Beyond association: How employees want to participate in their firms' corporate social performance," Business and Society Review 120: 83-113.

Hofstede, G. 2001. Culture's consequences: Comparing values, behaviors, institutions, and organizations across nations. New York: Sage.

Holtbrügge, D., Baron, A., and Friedmann, C. 2015. "Personal attributes, organizational conditions, and ethical attitudes: a social cognitive approach," Business Ethics: A European Review 24: 264-281.

Hare, R. 1993. Without conscience: The disturbing world of the psychopaths among us. New York: The Guilford Press.

Harris, G., Skilling, T., and Rice, M. 2001. "The construct of psychopathy," Crime and Justice 28: 197-264.

Harvard Law Review. 2003, "The Good, the bad, and their corporate codes of ethics: Enron, Sarbanes-Oxley, and the problems with legislating good behavior," Harvard Law Review 116: 2123-2141. 
Conscientious Objections to Corporate Wrongdoing

Harvard Law Review. 2011. "Recent Legislation," Harvard Law Review 124: 18291836.

Hill, T. 1998, "Four conceptions of conscience," in I. Shapiro and R. Adams, eds., Integrity and Conscience. New York: New York University Press, pp. 1-52.

Hill, T. 2000. Respect, pluralism, and justice: Kantian perspectives. New York: Oxford University Press.

Hofstede, G. (2001). Culture's consequences: Comparing values, behaviors, institutions, and organizations across nations. New York: Sage.

Kaptein, M. 2004. "Business codes of multinational firms: What do they say?" Journal of Business Ethics 50: 13-31.

Kaptein, M., and Schwartz, M. 2008. "The effectiveness of business codes: A critical examination of existing studies and the development of an integrated research model," Journal of Business Ethics 77: 111-127.

Kaptein, M. 2011. "Toward effective codes: Testing the relationship with unethical behavior," Journal of Business Ethics 99: 233-251.

Kellerman, B. 2004. Bad leadership: What it is, how it happens, why it matters. Boston: Harvard University Press.

Kellerman, B. 2008. Followership: How followers are creating change and changing leaders. Boston: Harvard University Press.

Kellerman, B. 2012. The end of leadership. New York: Harper Collins.

Kelly, R. 1992. The power of followership: How to create leaders people want to follow ... And followers who lead themselves. New York: Doubleday.

Kelman, H., and Hamilton, L. 1989. Crimes of obedience. New Haven: Yale University Press. 
Conscientious Objections to Corporate Wrongdoing

Knights, D., and O'Leary, M. 2015. "Reflecting on corporate scandals: The failure of ethical leadership," Business Ethics: A European Review 14: 359-366.

Kukathas, C. 2003. The Liberal archipelago. Oxford: Oxford University Press.

Langston, D. 2001. Conscience and other virtues. University Park, PA: Pennsylvania University Press.

Levenson, M. 1992. "Rethinking psychopathy," Theory and Psychology 2: 51-71.

Malti, T., and Krettenauer, T. 2013. "The relation of moral emotion attributions to prosocial and antisocial behavior: A meta-analysis," Child Development 84: $397-$ 412.

Marx, G. 1981. "Ironies of social control: Authorities as contributors to deviance through escalation, nonenforcement and covert facilitation," Social Problems 28: 221-246.

Miceli, M., Near, J., and Dworkin, T. 2008. "A word to the wise: How managers and policy-makers can encourage employees to report wrongdoing," Journal of Business Ethics 86: 379-396.

Miceli, M., Near, J. 2013. “An international comparison of the incidence of public sector whistle-blowing and the prediction of retaliation: Australia, Norway, and the US," Australian Journal of Public Administration, 72: 433-446.

Milgram, S. 1974. Obedience to authority. New York: Harper and Row.

Misangyi, V., Weaver, G., and Elms, H. 2008, “Ending corruption: The interplay between institutional logics, resources, and institutional entrepreneurs," Academy of Management Review 33: 750-770.

Moore, G. 2015. “Corporate character, corporate virtues," Business Ethics: A European Review 24: 99-113. 
Conscientious Objections to Corporate Wrongdoing

Morales-Sánchez, R., and Cabello-Medina, C. 2015. "Integrating character in management: Virtues, character strengths, and competencies," Business Ethics: A European Review 24: 156-174.

Moberly, R. 2006. Sarbanes-Oxley's Structural Model To Encourage Corporate Whistleblowers,” Birmingham Young University Law Review, 2006: 1106-1109.

Nieuwenboer, N., and Kaptein, M. 2008. "Spiraling down into corruption: A dynamic analysis of the social identity processes that cause corruption in organizations to grow," Journal of Business Ethics 83: 133-146.

Nunner-Winkler, G., and Sodian, B. 1988. “Children's understanding of moral emotions," Child Development 59: 1323-1338.

Patsuris, P. 2002 August 26. "The Corporate Scandal Sheet," Forbes Magazine. Forbes http://www.forbes.com/2002/07/25/accountingtracker.html, accessed 2 September 2015. From Forbes website.

O’Sullivan, P. and Ngau, O. 2014. "Whistleblowing: a critical philosophical analysis of the component moral decisions of the act and some new perspectives on its moral significance," Business Ethics: A European Review 23: 401-415.

Pech, R., and Slade, B. 2007. "Organizational sociopaths: Rarely challenged, often promoted. Why?" Society and Business Review 3: 254-269.

Pianalto, M. 2011. "Moral conviction,” Journal of Applied Philosophy, 28: 381-395.

Pitt, H., and Groskaufmanis, K. 1990. "Minimizing corporate civil and criminal liability: A second look at corporate codes of conduct," Georgetown Law Journal 78: I58298.

Preuss, L. 2009. “Codes of conduct in organizational context: From cascade to latticework of codes," Journal of Business Ethics 94: 471-487. 
Conscientious Objections to Corporate Wrongdoing

Rafalko, R. 2003. "A Caution about recent trends in ethics compliance programs," Business and Society Review 108: 115-126.

Rauthmann, J., and Kolar, G. 2012. "How "dark" are the dark traits? Examining the perceived darkness of narcissism, Machiavellianism and psychopathy," Personality and Individual Differences 53: 884-889.

Skivenes, M. and S.C. Trygstad. 2010. "When whistle-blowing works: The Norwegian case," Human Relations 63: 1071-1098.

Sorabji, R. 2014. Moral conscience through the ages. Oxford: Oxford University Press. Sorkin, A. 2010. Too big to fail. New York: Penguin.

Stevens, G., Deuling, J., and Armenakis, A. 2012. "Successful psychopaths: Are they unethical decision-makers and why?” Journal of Business Ethics 105: 139-149.

Stout, L. 2006. Taking conscience seriously. UCLA School of Law, Law-Econ Research Paper No. 06-20; Free Enterprise: Values in Action Conference Series. Available at SSRN: $\underline{\text { https://ssrn.com/abstract }=929048}$

Sulmasy, P. 2008. What is conscience and why is respect for it so important? Theoretical Medicine and Bioethics 29: 135-149.

Vaughn, D. 1982. "Toward understanding unlawful organizational behavior," Michigan Law Review 80: 1377-1402.

Vitacco, M., Erickson, S., and Lishner, D. 2013. “Comment: Holding psychopaths morally and criminally culpable," Emotion Review 5: 423-425.

Weaver, G. R. 2006, "Virtue in Organizations: Moral Identity as a Foundation for Moral Agency," Organization Studies 27: 341-368.

Weitzel, P., and Rodgers, Z. (2015). "Broad shareholder value and the inevitable role of conscience," New York University Journal of Law and Business 35: 35-96. 
Conscientious Objections to Corporate Wrongdoing

Wexler, M. 2008. "Conjectures on systemic psychopathy: Reframing the contemporary corporation," Society and Business Review 3: 224-238.

Wiesel, E. 1969. The town beyond the wall. New York: Avon Books.

Wright, C., and Rwabizambuga, A. 2006. "Institutional pressures, corporate reputation, and voluntary codes of conduct: An examination of the Equator Principles," Business and Society Review 111: 89-117. 